\title{
Detection of clonality in follicular lymphoma using formalin-fixed, paraffin-embedded tissue samples and BIOMED-2 immunoglobulin primers
}

\author{
Ellen Berget, ${ }^{1}$ Lars Helgeland, ${ }^{1}$ Anders Molven, ${ }^{1,2}$ Olav Karsten Vintermyr ${ }^{1,2}$
}

'Department of Pathology, The Gade Institute, Haukeland University Hospital, Bergen, Norway

${ }^{2}$ Section for Pathology, The Gade Institute, University of Bergen, Bergen, Norway

\section{Correspondence to}

Professor Olav Karsten Vintermyr, Department of Pathology, The Gade Institute, Haukeland University Hospital, N-5021 Bergen, Norway; olav. vintermyr@helse-bergen.no

Accepted 4 October 2010 Published Online First 28 October 2010

\section{ABSTRACT}

Aims The BIOMED-2 multiplex PCR protocol is a commonly used procedure for assessing B cell clonality in lymphoma diagnostics. Follicular lymphoma poses a special challenge for PCR-based analyses because of high prevalence of somatic hypermutations in the rearranged immunoglobulin (IG) domains. This study aimed to evaluate the BIOMED-2 protocol performance in detection of $B$ cell clonality in follicular lymphoma using formalin-fixed, paraffin-embedded (FFPE) tissue.

Methods FFPE samples from 118 patients diagnosed with follicular lymphoma in the period 1998-2008 were used in the study. Clonality of IG heavy $(/ G H)$ and light chains $(I G K, I G L)$ was assessed using a PCR procedure that was optimised for FFPE tissue.

Results The highest clonal detection rates were 67.8\% with the IGH $\mathrm{V}_{\mathrm{H}}-\mathrm{FR} 2-\mathrm{J}_{\mathrm{H}}$ assay and $66.1 \%$ with the IGK $V_{\kappa}-\mathrm{J} \kappa$ assay. Clonality was detected in $94.9 \%$ of all FFPE follicular lymphoma samples when all assays were combined. FFPE samples stored for $1-5$ years did not perform significantly differently from those stored for 6-11 years. Interobserver agreement of clonality was tested for all analyses. The lowest score (Cohen's $\kappa$ value $=0.56)$ was observed for the IGK VK-JK clonality assay.

Conclusions An improved PCR protocol for detection of clonality in FFPE samples using BIOMED-2 IG primers is presented. For best performance, a combination of $I G H$ and IGK analyses is recommended.

\section{INTRODUCTION}

PCR assays for immunoglobulin (IG) gene rearrangements are used to distinguish reactive from malignant B cell proliferations in cases that are difficult to assess morphologically and immunophenotypically. ${ }^{2}$ Many different PCR strategies for IG clonality testing have been described. ${ }^{3-9}$ Standardised PCR assays, developed by the BIOMED-2 group, are now available for the analysis of complete and incomplete $I G H$, as well as $I G K$ and $I G L$, gene rearrangements. ${ }^{10}$

The BIOMED-2 assays have been extensively validated for fresh and frozen tissues. ${ }^{10-13}$ However, FFPE samples constitute the majority of diagnostic biopsies submitted for analysis in most pathology laboratories. The fixation and storage of tissues has a well-known impact on DNA integrity. ${ }^{14} 15$ Generally, DNA fragments up to 200-300 base pairs (bp) can be reliably amplified from FFPE tissues. ${ }^{16} 17$ Although the BIOMED-2 primers were designed so that the PCR products would be $<300$ bp preferably, they have been found to be less efficient in the few FFPE specimens that have been tested. $^{10}$

One important limitation in evaluation of rearranged IG genes by PCR is related to the frequency of somatic hypermutations arising in stimulated germinal centre B cells. Such mutations reduce binding efficiency of the complete $I G H$ rearrangement primers. Hence, the detection of clonality by IG clonality assays in postgerminal centre B cell malignancies, such as in follicular lymphomas, is more challenging than in other lymphoma types. ${ }^{10} 1118$

The aim of the present study was to evaluate the performance of the BIOMED-2 IG primers in FFPE samples of follicular lymphoma. We also describe modifications of the original BIOMED-2 protocol that allow more successful application for FFPE biopsies.

\section{MATERIALS AND METHODS \\ Tissue specimens}

One FFPE tissue block from each of 118 patients diagnosed with follicular lymphoma in the period 1998-2008 was obtained from the archives of the Department of Pathology, Haukeland University Hospital, Bergen, Norway. Sixty-two (53\%) of the specimens were from 1998 to 2003, and the remaining were from 2004 to 2008. The specimens were biopsies or surgical resections from lymph nodes $(\mathrm{n}=102)$ and extranodal sites (gastrointestinal tract $(n=7)$, tonsils (2), salivary glands (2), ovary (1), uterus (1), ocular adnexa (1), brain (1) and skin (1)). Before molecular analyses, all cases were re-evaluated by a haematopathologist (LH) employing the WHO classification of lymphoid neoplasms. ${ }^{19}$ Among the cases, 49 were grade 1, 42 were grade 2, 20 were grade $3 \mathrm{~A}$, and 7 were grade $3 \mathrm{~B}$. Areas of diffuse large $\mathrm{B}$ cell lymphoma were observed in nine of the grade 3 lymphomas. No cases with partial nodal involvement or in situ follicular lymphoma were included. FFPE samples from 10 reactive tonsils were included as control tissue.

\section{DNA extraction}

Two $10 \mu \mathrm{m}$ sections were cut from each paraffin block. The sections were deparaffinised with xylene and dehydrated in 100\% ethanol, before overnight proteinase $\mathrm{K}(20 \mathrm{mg} / \mathrm{ml})$ digestion. An automated workstation (BioRobot M48; Qiagen, Hilden, Germany) was used for DNA extraction. DNA concentration and quality of DNA were determined by spectrophotometry (ND1000; NanoDrop Technologies, Wilmington, Delaware, USA). Average 
Figure 1 (A) Polyclonal curves for the IGH $\mathrm{V}_{\mathrm{H}-\mathrm{FR}}-\mathrm{J}_{\mathrm{H}}$ (left) assay and the $\mathrm{V}_{\mathrm{H}}-$ FR1-JH (right) assay using the standard BIOMED-2 protocol, the BIOMED-2 protocol with 38 PCR cycles and a modified BIOMED-2 protocol (38 PCR cycles and a commercial multiplex PCR kit); nt, nucleotide. (B) Example of the three protocols applied on the set of BIOMED-2 control genes. The same sample was used for each protocol.

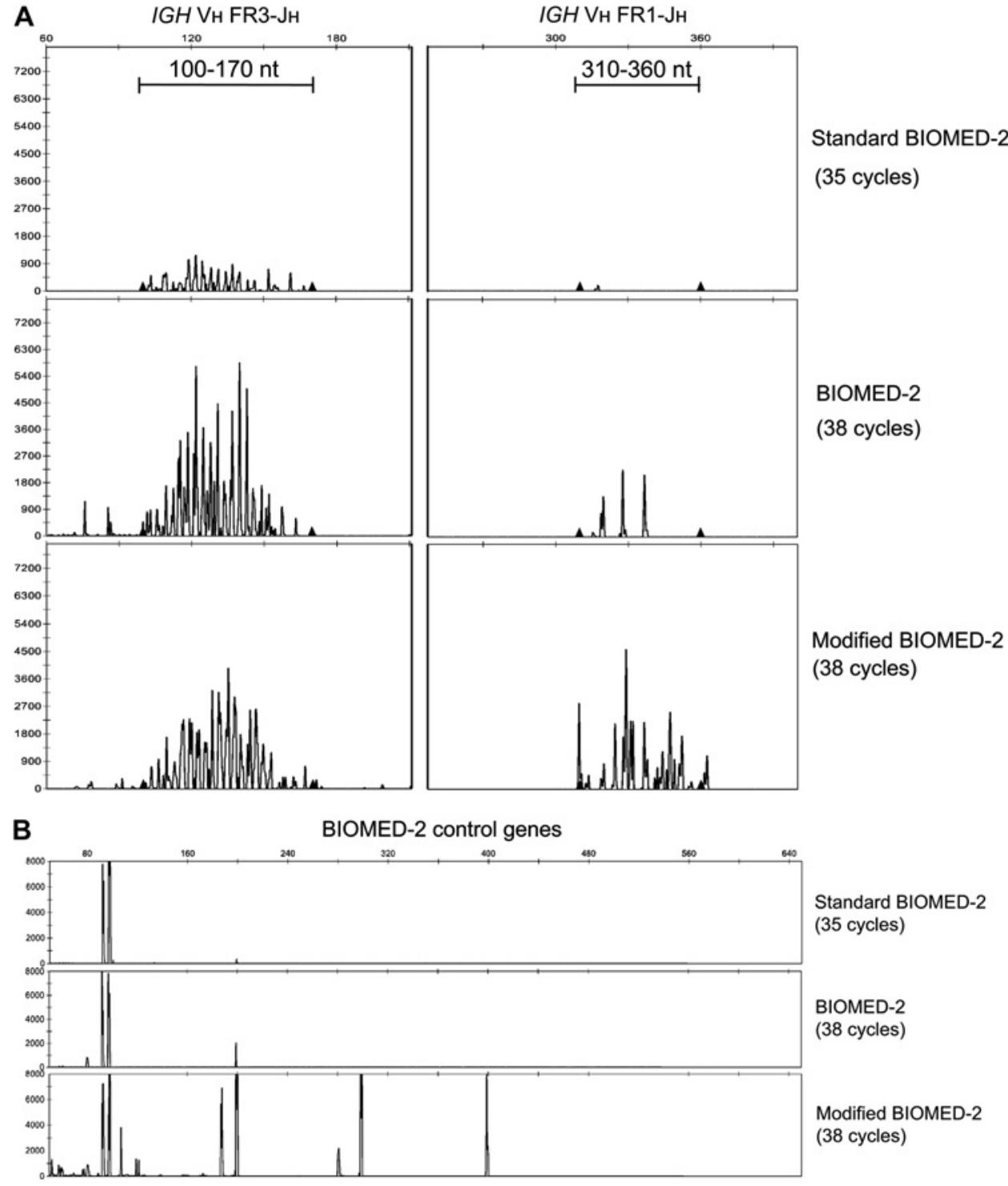

DNA concentration, OD260/280 and OD260/230 ratios were $73 \mathrm{ng} / \mu \mathrm{l}$ (range $6-207 \mathrm{ng} / \mu \mathrm{l}$ ), 1.79 and 1.50 , respectively. The quality of each DNA sample was also analysed by the BIOMED2 PCR control genes. ${ }^{10}$

\section{Multiplex PCR amplification}

The clonality analyses were adapted for archival tissue by using the Multiplex PCR kit (catalogue no. 206143; Qiagen) with HotStarTaq DNA polymerase. All eight BIOMED-2 IG primer sets were run separately. ${ }^{10}$ All reverse primers were labelled with fluorescent dye (6-FAM). The modified BIOMED-2 protocol was carried out by mixing $2.5 \mu \mathrm{l}$ primer mix ( $2 \mu \mathrm{M}$ of each primer), $12.5 \mu \mathrm{l}$ of the Multiplex buffer and $2.5 \mu \mathrm{l}$ DNA template to a final reaction volume of $25 \mu \mathrm{l}$ by adding $\mathrm{H}_{2} \mathrm{O}$. PCR conditions were as follows: an initial activation step $\left(95^{\circ} \mathrm{C}, 15 \mathrm{~min}\right), 38$ cycles consisting of denaturation $\left(95^{\circ} \mathrm{C}, 45 \mathrm{~s}\right)$, annealing of PCR primers $\left(60^{\circ} \mathrm{C}, 90 \mathrm{~s}\right)$ and extension $\left(72^{\circ} \mathrm{C}, 90 \mathrm{~s}\right)$, and a final extension step $\left(72^{\circ} \mathrm{C}\right.$ for $10 \mathrm{~min}$, followed by cooling to $\left.4^{\circ} \mathrm{C}\right)$. All samples were run with undiluted and fivefold-diluted template DNA. Polyclonal and non-template controls were always included. The PCR products were subjected to fragment analysis on an ABI 3100 capillary sequencer (Applied Biosystems, Foster City, California, USA).

\section{Assessment of clonality and interobserver agreement}

Identification of one or two definite and consistent PCR peak(s) by fragment analysis within the expected size range was interpreted as positive for clonality. Discrete peaks that were located in the centre of the expected size range, or were associated with a polyclonal background, were interpreted as polyclonal. Some samples yielded few amplified fragments (number <3-4),

Table 1 Clonal rearrangement detected in formalinfixed, paraffin-embedded follicular lymphomas, and level of agreement estimated by Cohen's $\kappa$

\begin{tabular}{|c|c|c|}
\hline PCR assay & $\begin{array}{l}\text { Clonality detection } \\
\text { rate }(\%), n=118\end{array}$ & Cohen's $K$ \\
\hline IGH VH-FR1-JH & 57.6 & 0.93 \\
\hline IGH $\mathrm{V}_{\mathrm{H}}-\mathrm{FR} 2-\mathrm{J}_{\mathrm{H}}$ & 67.8 & 0.89 \\
\hline IGH VH-FR3-JH & 38.1 & 0.91 \\
\hline IGH DH-JH & 8.5 & 0.84 \\
\hline IGH Dн7-JH & 0 & ND \\
\hline IGK VК-ЈK & 66.1 & 0.56 \\
\hline IGK VK/intron-Kde & 50.0 & 0.88 \\
\hline$I G L V \lambda-J \lambda$ & 8.5 & 0.73 \\
\hline
\end{tabular}

ND, not determined. 
Table 2 The combined use of complete IGH and IGK rearrangement assays improves clonality detection in formalin-fixed, paraffin-embedded follicular lymphoma samples

\begin{tabular}{|c|c|c|c|c|}
\hline \multicolumn{2}{|c|}{ Combined BIOMED-2 PCR assays } & \multirow{2}{*}{$\begin{array}{l}\begin{array}{l}\text { No. of } \\
\text { assays }\end{array} \\
3\end{array}$} & \multirow{2}{*}{$\begin{array}{l}\text { Clonality detection } \\
\text { rate }(\%), \mathbf{n = 1 1 8}\end{array}$} & \multirow{2}{*}{$\begin{array}{l}\text { Samples with a single clonal } \\
\text { result }(\%), \mathbf{n = 1 1 8} \\
19.5\end{array}$} \\
\hline IGH & $V_{H}-F R 1-J_{H}, V_{H}-F R 2-J_{H}, V_{H}-F R 3-J_{H}$ & & & \\
\hline$I G K$ & VК-Јк, VК/intron-Kde & 2 & 82.2 & 48.3 \\
\hline$I G H+I G K$ & $\mathrm{~V}_{\mathrm{H}}-\mathrm{FR} 2-\mathrm{J}_{\mathrm{H}}, \mathrm{V}_{\kappa}-\mathrm{J}_{\kappa}$ & 2 & 86.4 & 39.0 \\
\hline$I G H+I G K$ & VH-FR2-JH, VH-FR3-JH, VК-JК & 3 & 91.5 & 31.4 \\
\hline$I G H+I G K$ & $\begin{array}{l}\text { Vн-FR2-ЈH, } V_{H}-\mathrm{FR} 3-\mathrm{J}_{\mathrm{H}}, V_{\kappa}-\mathrm{J}_{\kappa}, V_{\kappa} / \text { intron- } \\
\text { Kde }\end{array}$ & 4 & 94.9 & 20.3 \\
\hline$I G H+I G K$ & $\begin{array}{l}V_{\mathrm{H}}-\mathrm{FR} 1-\mathrm{J}_{\mathrm{H}}, \mathrm{V}_{\mathrm{H}}-\mathrm{FR} 2-\mathrm{J}_{\mathrm{H}}, \mathrm{V}_{\mathrm{H}}-\mathrm{FR} 3-\mathrm{J}_{\mathrm{H}}, \mathrm{V}_{\kappa}- \\
\mathrm{J}_{\kappa}, \mathrm{V}_{\kappa} \text { /intron-Kde }\end{array}$ & 5 & 94.9 & 15.3 \\
\hline
\end{tabular}

per number of assays $(2,3,4$ and 5$)$ are shown.

fragments of low intensity (products $<2000$ fluorescent units), or even no amplified products. These were regarded as lowintensity curves, and were classified as polyclonal for the purpose of this study.

As previously described, ${ }^{2} 10$ peaks just outside the $5-95 \%$ size ranges were accepted as true rearrangement products. Two samples showed peaks of approximately $234 \mathrm{bp}$ using the $I G H$

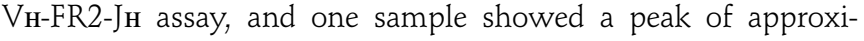
mately 94 bp using the IGH VH-FR3-JH assay. These peaks were considered undersized, and the samples were sequenced for evidence of clonality.

All samples were assessed for clonality by two independent raters $(\mathrm{EB}, \mathrm{OKV})$ before a consensus was established. Agreement between raters was expressed using Cohen's $\kappa$ coefficient. ${ }^{20} \mathrm{~A} \kappa$ value of 1 indicated perfect agreement, whereas a $\kappa$ value of 0 indicated no agreement. ${ }^{21}$

\section{Statistical analysis}

The $\chi^{2}$ test was used to compare frequencies. Where applicable, Fisher's exact test was performed to compare two categorical variables. A significant finding was defined as a $p$ value $<0.05$. All statistical analysis were carried out using the statistical package SPSS Statistics 17.0 (SPSS, Chicago, Illinois, USA).

\section{RESULTS}

\section{Evaluation of clonality}

In a pilot study, three lymphoma samples were analysed with the aim of optimising PCR conditions for FFPE tissue. Three various protocols were tested: (1) the standard BIOMED-2 procedure, which includes 35 PCR cycles $^{10}$; (2) the standard BIOMED-2 procedure with the number of PCR cycles increased to 38; and (3) a modified BIOMED-2 procedure using a commercial multiplex PCR kit and 38 PCR cycles (see Materials and methods). For assays with amplified fragments $<250 \mathrm{bp}$, such as the IGH VH-FR3-JH assay, good performance with respect to obtaining a smooth polyclonal profile was achieved by increasing the number of PCR cycles (figure 1A). However, for assays with larger amplified fragments, the modified BIOMED-2 protocol was superior.
All DNA samples were also tested using the BIOMED-2 control genes. PCR products of $>300 \mathrm{bp}$ were observed in 11 samples $(9.3 \%)$ using the standard BIOMED-2 procedure, in 56 samples $(47.5 \%)$ when the number of PCR cycles were increased to 38 , and in 112 samples $(94.4 \%$ ) when the modified BIOMED2 protocol was used (figure $1 \mathrm{~B}$ ). The modified BIOMED-2 protocol was thereafter employed for assessment of clonality throughout the study.

The clonality detection rate obtained by each assay in all FFPE samples $(n=118)$ is shown in table 1 . Six cases did not show any clonal rearrangements; supplementary fluorescence in situ hybridisation analysis (BCL2 and BCL6 split-apart approach) revealed BCL2 translocation in four of these cases, BCL2 amplification in one, and one was negative (data not shown).

Determination of clonality requires experience and cannot be assessed by fully objective means. The level of agreement was therefore tested on all assays (table 1$)$. Cohen's $\kappa$ value was

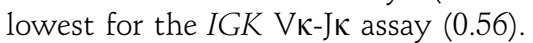

The combined use of three complete IGH rearrangement assays established clonality in 94 of the 118 (79.7\%) cases

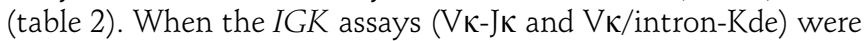
used, clonality was found in $97(82.2 \%)$ cases. By using a combination of the three complete IGH rearrangement assays and the two IGK assays, clonality was achieved in $94.9 \%$ of the samples. Of note, the incomplete IGH assays (DH-JH and DH7-JH) and the IGL assay ( $\mathrm{V} \lambda$-J $\lambda$ ) did not identify any clonal result that was not identified by the other assays.

\section{Effect of age and DNA concentration}

Clonality detection using the three complete IGH rearrangement assays was compared on blocks from the periods 1998-2003 and 2004-2008. There was a tendency to a higher rate of clonality detection on blocks from 2004 to 2008 than on blocks from 1998 to 2003 for the $\mathrm{V}_{\mathbf{H}}-\mathrm{FR} 1-\mathrm{JH}_{\mathbf{H}}$ and $\mathrm{VH}_{\mathrm{H}} \mathrm{FR} 2-\mathrm{JH}_{\mathbf{H}}$ assays, but not for the VH-FR3-JH assay (table 3).

For the $\mathrm{VH}_{\mathbf{H}}$-FR1-Jн and $\mathrm{VH}_{\mathrm{H}} \mathrm{FR} 2-\mathrm{JH}_{\mathrm{H}}$ assays, the amount of DNA did not have a significant effect on detection of clonality on the 2004-2008 samples (table 3). However, among the 1998-2003 samples, we noted a somewhat lower detection rate for those

Table 3 Clonality detection rate by the complete IGH rearrangement assays according to DNA sample concentration and period stored

\begin{tabular}{|c|c|c|c|c|c|c|c|c|c|c|}
\hline \multirow[b]{2}{*}{ DNA (ng/ $/ \mathrm{l})$} & \multirow[b]{2}{*}{$\mathbf{n}$} & \multicolumn{3}{|c|}{$\%$ Clonality $V_{\mathrm{H}}-\mathrm{FR} 1-\mathrm{J}_{\mathrm{H}}$} & \multicolumn{3}{|c|}{$\%$ Clonality $V_{\mathrm{H}}-\mathrm{FR2}-\mathrm{J}_{\mathrm{H}}$} & \multicolumn{3}{|c|}{$\%$ Clonality $\mathbf{V}_{\mathrm{H}-\mathrm{FR3}-\mathrm{J}_{\mathrm{H}}}$} \\
\hline & & $1998-2003$ & $2004-2008$ & All samples & $1998-2003$ & $2004-2008$ & All samples & $1998-2003$ & $2004-2008$ & All samples \\
\hline$<50$ & 45 & $37.5(6 / 19)$ & $65.4(17 / 26)$ & $51.1(23 / 45)$ & $57.9(11 / 19)$ & $69.2(18 / 26)$ & $64.4(29 / 45)$ & $36.8(7 / 19)$ & $23.1(6 / 26)$ & $28.9(13 / 45)$ \\
\hline $50-100$ & 40 & $57.1(12 / 21)$ & $63.1(12 / 19)$ & $60.0(24 / 40)$ & $66.7(14 / 21)$ & $68.4(13 / 19)$ & $67.5(27 / 40)$ & $57.1(12 / 21)$ & $36.8(7 / 19)$ & $47.5(19 / 40)$ \\
\hline$>100$ & 33 & $63.6(14 / 22)$ & $63.6(7 / 11)$ & $63.6(21 / 33)$ & $72.7(16 / 22)$ & $72.7(8 / 11)$ & $72.7(24 / 33)$ & $45.5(10 / 22)$ & $27.2(3 / 11)$ & $39.3(13 / 33)$ \\
\hline Total & 118 & $51.6(32 / 62)$ & $64.3(36 / 56)$ & $57.6(68 / 118)$ & $66.1(41 / 62)$ & $69.6(39 / 56)$ & $67.8(80 / 118)$ & $46.8(29 / 62)$ & $28.6(16 / 56)$ & $38.1(45 / 118)$ \\
\hline
\end{tabular}


Table 4 Frequency of low-intensity curves in the complete IGH and IGK rearrangements assays according to DNA sample concentration

\begin{tabular}{|c|c|c|c|c|c|c|}
\hline \multirow[b]{2}{*}{ DNA (ng/ $\mu$ l) } & \multirow[b]{2}{*}{$n$} & \multicolumn{5}{|c|}{ Frequency of low-intensity curves (\%) } \\
\hline & & VH-FR1-JH & $V_{H}-F R 2-J_{H}$ & $\mathbf{V}_{\mathrm{H}-\mathrm{FR} 3-\mathrm{J}_{\mathrm{H}}}$ & Vк-Јк & VK/intron-Kde \\
\hline$<50$ & 45 & 28.9 & 11.1 & 4.4 & 2.2 & 46.7 \\
\hline $50-100$ & 40 & 17.5 & 12.5 & 2.5 & 2.5 & 30.0 \\
\hline$>100$ & 33 & 15.2 & 9.1 & 3.0 & 3.0 & 27.3 \\
\hline Total & 118 & 21.2 & 11.0 & 3.4 & 2.5 & 35.6 \\
\hline
\end{tabular}

samples with the lowest $(<50 \mathrm{ng} / \mu \mathrm{l})$ concentration of DNA. On the other hand, the detection of clonality in the $\mathrm{VH}_{\mathrm{H}}-\mathrm{FR} 3-\mathrm{JH}_{\mathrm{H}}$ assay appeared not to be negatively affected by storage or a low DNA content.

Also the occurrence of low-intensity curves was evaluated in relation to storage time and DNA content for the three complete IGH rearrangement assays and the two IGK assays (table 4). Increased numbers of low-intensity curves were found for the $I G H \mathrm{VH}-\mathrm{FR} 1-\mathrm{JH}$ and the IGK VK/intron-Kde assays $(\mathrm{p}<0.001)$ as compared with a PCR assay with shorter amplified fragments, such as $I G H$ VH-FR2-JH. It was also observed that the numbers of such low-intensity curves were highest for samples with DNA concentration $<50 \mathrm{ng} / \mu \mathrm{l}$.

\section{DISCUSSION}

The performance of the BIOMED-2 IG primers on routine diagnostic FFPE tissue and more specifically on follicular lymphomas has not been extensively investigated. Only a small number of samples or a limited number of analyses have been reported on. ${ }^{22-25}$

In our study, the clonality detection rate in FFPE follicular lymphoma was somewhat lower than previously reported for fresh/frozen follicular lymphoma samples. ${ }^{10} 11 \quad 1326$ Only the

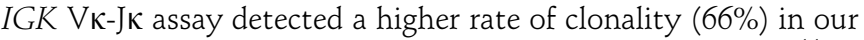
study than the rate reported (63\%) for fresh/frozen samples. ${ }^{11}$ In addition, the $\mathrm{V} \kappa-\mathrm{J} \kappa$ assay differed from the other BIOMED-2 assays with lower interobserver agreement by Cohen's $\kappa(0.56)$

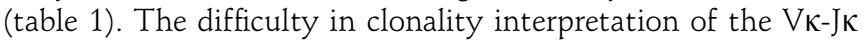
assay can be explained by the restricted CDR3 region in these rearrangements, and it has also been noticed earlier by McClure et $a l^{23}$ and Evans et al. ${ }^{11}$

Used in combination, the detection rates for the three complete $I G H$ and the two IGK assays were $79.7 \%$ and $82.2 \%$, respectively (table 2). Previous studies on FFPE follicular lymphomas have reported lower detection rate (range 35-55\%) for the complete BIOMED-2 IGH assays, ${ }^{22} 2327$ An improved clonality detection rate was also observed as compared with previously used primer systems. ${ }^{3} 28-30$ The clonality detection rate was further improved by combining the three complete IGH and the two $I G K$ rearrangements assays, and a clonal result was obtained in $94.9 \%$ of the cases.

To reflect the broad range of DNA concentrations found in diagnostic samples, we did not attempt to standardise the DNA concentration. The samples were instead divided into three DNA concentration groups. In particular, for assays with amplified fragments $>250$ bp there was a tendency of a higher clonal yield with increasing amount of DNA (table 3). There was also a tendency to higher clonality detection rates in the samples from 2004 to 2008, as compared with the samples from 1998 to 2003 when DNA concentrations were $<100 \mathrm{ng} / \mu \mathrm{l}$. However, there was no statistical difference in these assays in the rate of clonality observed in the samples from 2004 to 2008 as compared with older samples. For some other assays, such as

\section{Take-home messages}

A modified BIOMED-2 PCR protocol showed improved performance for detection of clonality in follicular lymphomas on formalin-fixed, paraffin-embedded tissue samples.

- For diagnostic purposes, a combination of IGH and IGK analysis was recommended.

- Aged versus more recently obtained formalin-fixed, paraffinembedded samples did not perform significantly different with respect to detection of clonality.

the IGH VH-FR3-JH, a DNA content $<100 \mathrm{ng} / \mu \mathrm{l}$ performed better than a higher DNA content. The reason for this latter observation is not clear.

It has also been noted that false-negative clonality outcomes and amplification failure are more frequent in FFPE tissue than in fresh/frozen follicular lymphoma samples. ${ }^{25} 31$ In our study, some degree of amplification failure was observed in assays with

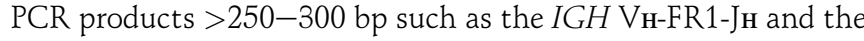
IGK VK/intron-Kde assays, and especially for samples with DNA concentrations $<50 \mathrm{ng} / \mu \mathrm{l}$ (table 4$)$. The problem of lowintensity curves does need close attention. Our results did, however, indicate that the problem was not significant enough to advocate a split diagnostic protocol to ensure a higher yield by PCR in those cases. The main reason for this was that we observed a high detection rate of clonality and that a panel of clonality assays should always be used for diagnostic purposes.

Funding The study was funded by a grant provided by Helse Vest, Haukeland University Hospital.

Competing interests None to declare.

Provenance and peer review Not commissioned; externally peer reviewed.

\section{REFERENCES}

1. Bench AJ, Erber WN, Follows GA, et al. Molecular genetic analysis of haematological malignancies II: mature lymphoid neoplasms. Int J Lab Hematol 2007:29:229-60.

2. Langerak AW, Groenen PJ, van Krieken JH, et al. Immunoglobulin/T-cell receptor clonality diagnostics. Expert Opin Med Diagn 2007;1:451-61.

3. Diss TC, Liu HX, Du MQ, et al. Improvements to B cell clonality analysis using PCR amplification of immunoglobulin light chain genes. J Clin Pathol 2002;55:98-101.

4. Derksen PWB, Langerak AW, Kerkhof $E$, et al. Comparison of different polymerase chain reaction-based approaches for clonality assessment of immunoglobulin heavychain gene rearrangements in B-cell neoplasia. Mod Pathol 1999;12:794-805.

5. Aubin J, Davi F, Nguyensalomon F, et al. Description of a novel FR1 IgH PCR strategy and its comparison with three other strategies for the detection of clonality in B-cell malignancies. Leukemia 1995;9:471-9.

6. Diss T, Pan L, Peng H, et al. Sources of DNA for detecting B cell monoclonality using PCR. J Clin Pathol 1994;47:493-6.

7. Brisco MJ, Tan LW, Orsborn AM, et al. Development of a highly sensitive assay, based on the polymerase chain reaction, for rare B-lymphocyte clones in a polyclona population. Br J Haematol 1990;75:163-7.

8. McCarthy KP, Sloane JP, Wiedemann LM. Rapid method for distinguishing clonal from polyclonal B cell populations in surgical biopsy specimens. J Clin Pathol 1990;43:429-32

9. Trainor KJ, Brisco MJ, Story CJ, et al. Monoclonality in B-lymphoproliferative disorders detected at the DNA level. Blood 1990;75:2220-2.

10. van Dongen JJM, Langerak AW, Bruggemann $M$, et al. Design and standardization of PCR primers and protocols for detection of clonal immunoglobulin and T-cell receptor gene recombinations in suspect lymphoproliferations: Report of the BIOMED-2 Concerted Action BMH4-CT98-3936. Leukemia 2003;17:2257-317.

11. Evans PAS, Pott C, Groenen P, et al. Significantly improved PCR-based clonality testing in B-cell malignancies by use of multiple immunoglobulin gene targets. Repor of the BIOMED-2 Concerted Action BHM4-CT98-3936. Leukemia 2007:21:207-14.

12. Langerak AW, Molina TJ, Lavender FL, et al. Polymerase chain reaction-based clonality testing in tissue samples with reactive lymphoproliferations: usefulness and pitfalls. A report of the BIOMED-2 Concerted Action BMH4-CT98-3936. Leukemia 2007:21:222-9. 
13. van Krieken J, Langerak AW, Macintyre EA, et al. Improved reliability of lymphoma diagnostics via PCR-based clonality testing: - Report of the BIOMED-2 concerted action BHM4-CT98-3936. Leukemia 2007;21:201-6.

14. Srinivasan $\mathbf{M}$, Sedmak D, Jewell S. Effect of fixatives and tissue processing on the content and integrity of nucleic acids. Am J Pathol 2002;161:1961-71.

15. Goelz SE, Hamilton SR, Vogelstein B. Purification of DNA from formaldehyde fixed and paraffin embedded human-tissue. Biochem Biophys Res Commun 1985; 130:118-26

16. Gillio-Tos A, De Marco L, Fiano V, et al. Efficient DNA extraction from 25-year-old paraffin-embedded tissues: study of 365 samples. Pathology (Phila) 2007;39:345-8.

17. Cawkwell L, Quirke P. Direct multiplex amplification of DNA from a formalin fixed, paraffin wax embedded tissue section. J Clin Pathol 2000;53:51-2.

18. Theriault C, Galoin S, Valmary S, et al. PCR analysis of immunoglobulin heavy chain $(\mathrm{lgH})$ and TcR-gamma chain gene rearrangements in the diagnosis of lymphoproliferative disorders: Results of a study of 525 cases. Mod Pathol 2000:13:1269-79.

19. Swerdlow SH, Campo E, Harris NL, et al, eds. WHO Classification of Tumours of Haematopoietic and Lymphoid Tissues. Lyon: International Agency for Research on Cancer (IARC), 2008:220-6.

20. Cohen J. A coefficient of agreement for nominal scales. Educ Psychol Meas 1960;20:37-46.

21. Landis JR, Koch GG. The measurement of observer agreement for categorical data. Biometrics 1977;33:159-74.

22. Halldorsdottir AM, Zehnbauer BA, Burack WR. Application of BIOMED-2 clonality assays to formalin-fixed paraffin embedded follicular lymphoma specimens: Superior performance of the IGK assays compared to IGH for suboptimal specimens. Leuk Lymphoma 2007:48:1338-43.
23. McClure RF, Kaur $P$, Pagel $E$, et al. Validation of immunoglobulin gene rearrangement detection by PCR using commercially available BIOMED-2 primers. Leukemia 2006;20:176-9.

24. Chen YL, Su IJ, Cheng HY, et al. BIOMED-2 protocols to detect clonal immunoglobulin and T-cell receptor gene rearrangements in B- and T-cell lymphomas in southern Taiwan. Leuk Lymphoma 2010:51:650-5.

25. Lukowsky A, Marchwat M, Sterry W, et al. Evaluation of B-cell clonality in archiva skin biopsy samples of cutaneous B-cell lymphoma by immunoglobulin heavy chain gene polymerase chain reaction. Leuk Lymphoma 2006;47:487-93.

26. Catherwood MA, Gonzalez D, Patton C, et al. Improved clonality assessment in germinal centre/postgerminal centre non-Hodgkin's lymphomas with high rates of somatic hypermutation. J Clin Pathol 2007;60:524-8.

27. Liu HX, Bench AJ, Bacon CM, et al. A practical strategy for the routine use of BIOMED-2 PCR assays for detection of B- and T-cell clonality in diagnostic haematopathology. Br J Haematol 2007:138:31-43.

28. Pai RK, Chakerian AE, Binder JM, et al. B-cell clonality determination using an immunoglobulin kappa light chain polymerase chain reaction method. J Mol Diagn 2005; 7:300-7.

29. Catherwood MA, Alexander HD, McManus DT, et al. Immunoglobulin gene rearrangement investigations in the diagnosis of lymphoid malignancies from formaldehyde-fixed biopsies. Leuk Lymphoma 2003;44:645-8.

30. Hoeve MA, Krol ADG, Philippo K, et al. Limitations of clonality analysis of B cell proliferations using CDR3 polymerase chain reaction. J Clin Pathol 2000:53:194-200.

31. Bagg A, Braziel RM, Arber DA, et al. Immunoglobulin heavy chain gene analysis in lymphomas-A multi-center study demonstrating the heterogeneity of performance of polymerase chain reaction assays. J Mol Diagn 2002;4:81-9. 